\title{
Methods for Studying Endocytotic Pathways of Herpesvirus Encoded G Protein-Coupled Receptors
}

\author{
Maša Mavri ${ }^{1,2}{ }^{(0)}$, Katja Spiess ${ }^{2}$, Mette Marie Rosenkilde ${ }^{2}\left(\mathbb{D}\right.$, Catrin Sian Rutland ${ }^{3}(\mathbb{D}$, \\ Milka Vrecl ${ }^{1}$ and Valentina Kubale ${ }^{1, *}$ \\ 1 Department of Anatomy, Histology with Embryology and Cytology, Institute of Preclinical Sciences, \\ Veterinary Faculty, University of Ljubljana, Gerbičeva 60, 1000 Ljubljana, Slovenia; \\ masa.mavri@vf.uni-lj.si (M.M.); milka.vrecl@vf.uni-lj.si (M.V.) \\ 2 Department of Biomedical Sciences, Faculty of Health and Medical Sciences, University of Copenhagen, \\ 2200 Copenhagen, Denmark; kspiess@sund.ku.dk (K.S.); rosenkilde@sund.ku.dk (M.M.R.) \\ 3 School of Veterinary Medicine and Science, Medical Faculty, Sutton, Bonington Campus, \\ University of Nottingham, Sutton Bonington LE12 5RD, UK; Catrin.Rutland@nottingham.ac.uk \\ * Correspondence: valentina.kubale@vf.uni-lj.si; Tel.: +386-1449-121
}

Academic Editor: Sławomir Filipek

Received: 31 October 2020; Accepted: 1 December 2020; Published: 3 December 2020

\begin{abstract}
Endocytosis is a fundamental process involved in trafficking of various extracellular and transmembrane molecules from the cell surface to its interior. This enables cells to communicate and respond to external environments, maintain cellular homeostasis, and transduce signals. G protein-coupled receptors (GPCRs) constitute a family of receptors with seven transmembrane alpha-helical domains (7TM receptors) expressed at the cell surface, where they regulate physiological and pathological cellular processes. Several herpesviruses encode receptors (vGPCRs) which benefits the virus by avoiding host immune surveillance, supporting viral dissemination, and thereby establishing widespread and lifelong infection, processes where receptor signaling and/or endocytosis seem central. vGPCRs are rising as potential drug targets as exemplified by the cytomegalovirus-encoded receptor US28, where its constitutive internalization has been exploited for selective drug delivery in virus infected cells. Therefore, studying GPCR trafficking is of great importance. This review provides an overview of the current knowledge of endocytic and cell localization properties of vGPCRs and methodological approaches used for studying receptor internalization. Using such novel approaches, we show constitutive internalization of the BILF1 receptor from human and porcine $\gamma-1$ herpesviruses and present motifs from the eukaryotic linear motif (ELM) resources with importance for vGPCR endocytosis.
\end{abstract}

Keywords: endocytosis; G-protein coupled receptors; herpesvirus; methods

\section{Importance of Endocytosis for Viral GPCRs}

Endocytosis encompasses different routes by which a cell uptakes extracellular material from the surface and transports it into the cell thereby maintaining homeostasis between the extracellular and intracellular environment [1]. Nutrients, receptor-ligand complexes, extracellular matrix, cell debris, bacteria, and viruses can enter the cell by different endocytic mechanisms [2,3]. Importantly, endocytosis is also linked with cellular signaling at the plasma membrane (PM) where receptors bind specific signaling molecules and initiate internalization [4].

Receptors located at the cell surface coordinate many different physiological processes in the cell. Among them, G protein coupled receptors (GPCRs) with seven transmembrane domains (7TM) are a major family of receptors able to stimulate important intracellular signaling pathways in response to various extracellular stimuli [5]. It has been recognized that after initial activation and desensitization 
on the cell membrane, GPCRs subsequently enter the cell via endocytosis. Endocytosis can occur either constitutively (without ligand stimulus) or in response to certain stimuli, including growth factors, viruses (Ebola, SARS and other coronaviruses), and different ligands [6]. In the cell, further sorting of internalized GPCRs between degradation and recycling pathways occurs. Therefore, cells can tightly regulate GPCR surface availability for further signaling events [7].

Endocytosis is also a mechanism used by several herpesviruses (for example Epstein-Barr virus, Kaposi's sarcoma associated herpesvirus, cytomegalovirus, and varicella zoster virus) for initial entry into the cell [8]. Herpesviruses are widespread DNA viruses employing a special bipartite life cycle where latent and lytic phases interchange in order to persist in the infected host for their whole life [9]. The herpesvirus virion consists of three main parts: a nucleocapsid containing linear double-stranded DNA, an envelope, and tegument. In the envelope, different glycoproteins are involved in the initial binding and endocytosis events upon infection of susceptible cells. Herpesvirus genomes encode between 100 to 200 proteins. These proteins are involved in DNA replication (e.g., DNA polymerase), viral entry, cell-to-cell spread, immunevasion, and pathogenesis. Among these regulatory proteins, herpesviruses encode GPCRs (vGPCRs). It is believed that during evolutionary processes, viruses took over genes for these receptors from their hosts and rearranged them to function in the benefit of the virus [10-12]. They imitate the function of endogenous human receptors and therefore use them to subvert cellular signaling, avoid cell immune responses, induce cell transformation, and support viral dissemination and replication [12,13].

Many vGPCRs resemble endogenous chemokine receptors structurally, and bind a broad spectrum of both endogenous and virally encoded chemokines, leading to activation of downstream signaling pathways [12,14]. Others are described as "orphan" vGPCRs for which no ligand has yet been identified. Additionally, BILF1 receptors, encoded by gamma-1 herpesviruses, have recently been recognized as the first immune evasive vGPCR able to downregulate surface MHC class I molecules at the cell surface [15]. Initial localization of these receptors in the cell, and additional trafficking, are important processes that control the signaling capacity of these receptors. Table 1 summarizes known viruses and viral GPCRs from the $\beta$ - and $\gamma$-herpesvirus family and their known endocytic and signaling pathways.

In this article, the most common endocytic pathways employed by GPCRs to enter the cell are reviewed, alongside the novel approaches used to study GPCR mediated endocytosis and endocytic properties of most commonly studied vGPCRs: US28, ORF74, and BILF1. 
Table 1. Examples of viral GPCRs (vGPCRs) from different herpesvirus families ( $\beta$ and $\gamma$ ) (Adapted from [16]).

\begin{tabular}{|c|c|c|c|c|c|}
\hline Family & Virus & Receptor & $\begin{array}{c}\text { Preferred Endocytic } \\
\text { Pathway }\end{array}$ & Signaling Pathways & G Protein Coupling \\
\hline \multirow[t]{12}{*}{$\beta$-Herpesviruses } & Human cytomegalovirus (CMV) & US27 & - & - & - \\
\hline & & US28 & $\begin{array}{l}\beta \text {-arrestin independent } \\
\text { clathrin-mediated, partly } \\
\text { through lipid rafts }\end{array}$ & $\begin{array}{c}\text { Constitutive } \\
\text { NFkB, NFAT, CREB, PLC, SRF, } \\
\text { STAT3, TCF/LEF, Ligand induced } \\
\text { PLC, MAPK }\end{array}$ & $\mathrm{G} \alpha_{\mathrm{q}}, \mathrm{G} \alpha_{\mathrm{i} / \mathrm{o}}, \mathrm{G} \alpha_{12 / 13}$ \\
\hline & & UL33 & - & $\begin{array}{l}\text { Constitutive } \\
\text { SRC, CREB }\end{array}$ & $G \alpha_{\mathrm{q}}, \mathrm{G} \alpha_{\mathrm{i}}, \mathrm{G} \alpha_{\mathrm{s}}$ \\
\hline & & UL78 & - & - & - \\
\hline & Human herpesvirus 6 & U12 & - & - & - \\
\hline & & U51 & - & - & - \\
\hline & Human herpesvirus 7 & U12 & - & - & - \\
\hline & & U51 & - & - & - \\
\hline & Mouse cytomegalovirus & M33 & - & $\begin{array}{c}\text { Constitutive } \\
\text { PLC, NFKB, CREB }\end{array}$ & $\mathrm{G} \alpha_{\mathrm{s}}$ \\
\hline & & M78 & - & - & - \\
\hline & Rat cytomegalovirus & $\mathrm{R} 33$ & - & $\begin{array}{l}\text { Constitutive } \\
\text { PLC, NFKB }\end{array}$ & $\mathrm{G} \alpha_{\mathrm{q}}, \mathrm{G} \alpha_{\mathrm{i}}$ \\
\hline & & R78 & - & - & - \\
\hline \multirow[t]{3}{*}{$\gamma$-Herpesviruses } & $\begin{array}{l}\text { Human herpesvirus } 8 \text { (HHV8 or } \\
\text { Kaposi's sarcoma virus (KSHV)) }\end{array}$ & ORF74 & $\begin{array}{c}\beta \text {-arrestin independent } \\
\text { clathrin mediated } \\
\text { constitutive endocytosis, } \\
\beta \text {-arrestin dependent } \\
\text { clathrin-mediated ligand } \\
\text { dependent endocytosis }\end{array}$ & $\begin{array}{c}\text { Constitutive and ligand induced } \\
\text { RAC1, PLC, PKC, AKT, } \\
\text { JNK-SAPK, LYN-SRC, GSK3, } \\
\text { JAK2-STAT3, HIF1 } \alpha, \text { PI3K } \gamma, \\
\text { calcineurin }\end{array}$ & $\mathrm{G} \alpha_{\mathrm{q}}, \mathrm{G} \alpha_{\mathrm{i}}, \mathrm{G} \alpha_{12 / 13}$ \\
\hline & Ateles herpesvirus (AtHV) & ORF74-AtHV & - & - & - \\
\hline & MouseHV68 & ORF74-MHV68 & - & $\begin{array}{l}\text { not constitutively active } \\
\text { PLC, MAPK, Akt, NFKB }\end{array}$ & $\mathrm{G} \alpha_{\mathrm{i}}$ \\
\hline
\end{tabular}


Table 1. Cont.

\begin{tabular}{|c|c|c|c|c|c|}
\hline Family & Virus & Receptor & $\begin{array}{l}\text { Preferred Endocytic } \\
\text { Pathway }\end{array}$ & Signaling Pathways & G Protein Coupling \\
\hline \multirow[t]{14}{*}{$\gamma$-Herpesviruses } & Equine HV2 (EHV2) & E1 & - & - & - \\
\hline & & E6 & - & - & - \\
\hline & & ORF74-EHV2 & - & - & $\mathrm{G} \alpha_{\mathrm{i}}$ \\
\hline & Herpesvirus Saimiri (HVS) & ECRF3 & - & - & - \\
\hline & Human Epstein barr virus (EBV) & BILF1 & - & $\begin{array}{c}\text { Constitutive } \\
\text { NFKB, NFAT, CREB }\end{array}$ & $\mathrm{G} \alpha_{\mathrm{i}}$ \\
\hline & $\begin{array}{l}\text { Rhesus lymphocryptovirus } \\
\text { (RhLCV) }\end{array}$ & BILF1 & - & $\begin{array}{l}\text { Constitutive } \\
\text { NFKB }\end{array}$ & $\mathrm{G} \alpha_{\mathrm{i}}$ \\
\hline & $\begin{array}{l}\text { Callitrichine herpesvirus } 3 \\
\text { (CalHv3) }\end{array}$ & BILF1 & - & $\begin{array}{l}\text { Constitutive } \\
\text { NFKB, NFAT }\end{array}$ & $\mathrm{G} \alpha_{\mathrm{i}}$ \\
\hline & $\begin{array}{c}\text { Pan troglodytes lymphocryptovirus } \\
1 \text { (PtroLCV1) }\end{array}$ & BILF1 & - & $\begin{array}{l}\text { Constitutive } \\
\text { NFKB }\end{array}$ & $G \alpha_{i}$ \\
\hline & $\begin{array}{l}\text { Gorilla gorilla lymphocryptovirus } 1 \\
\text { (GgorLCV1) }\end{array}$ & BILF1 & - & - & - \\
\hline & $\begin{array}{c}\text { Gorilla gorilla lymphocryptovirus } 2 \\
\text { (GgorLCV2) }\end{array}$ & BILF1 & - & - & - \\
\hline & $\begin{array}{c}\text { Pongo pygmaeus } \\
\text { lymphocryptovirus } 1 \text { (PpygLCV1) }\end{array}$ & BILF1 & - & $\begin{array}{l}\text { Constitutive } \\
\text { NFKB }\end{array}$ & $\mathrm{G} \alpha_{\mathrm{i}}$ \\
\hline & $\begin{array}{c}\text { Pongo pygmaeus } \\
\text { lymphocryptovirus } 2 \text { (PpygLCV2) }\end{array}$ & BILF1 & - & - & - \\
\hline & $\begin{array}{l}\text { Symphalangus syndactylus } \\
\text { lymphocryptovirus } 1 \text { (SsynLCV1) }\end{array}$ & BILF1 & - & $\begin{array}{l}\text { Constitutive } \\
\text { NFKB, NFAT }\end{array}$ & $G \alpha_{i}$ \\
\hline & $\begin{array}{l}\text { Symphalangus syndactylus } \\
\text { lymphocryptovirus } 2 \text { (SsynLCV2) }\end{array}$ & BILF1 & - & - & - \\
\hline
\end{tabular}




\begin{tabular}{|c|c|c|c|c|c|}
\hline Family & Virus & Receptor & $\begin{array}{l}\text { Preferred Endocytic } \\
\text { Pathway }\end{array}$ & Signaling Pathways & G Protein Coupling \\
\hline \multirow[t]{6}{*}{$\gamma$-Herpesviruses } & $\begin{array}{c}\text { Macaca fascicularis } \\
\text { lymphocryptovirus } 1 \text { (MfasLCV1) }\end{array}$ & BILF1 & - & - & - \\
\hline & $\begin{array}{c}\text { Erythrocebus patas } \\
\text { lymphocryptovirus } 1 \text { (EpatLCV1) }\end{array}$ & BILF1 & - & - & - \\
\hline & $\begin{array}{c}\text { Piliocolobus badius } \\
\text { lymphocryptovirus } 1 \text { (PbadLCV1) }\end{array}$ & BILF1 & - & - & - \\
\hline & $\begin{array}{c}\text { Ateles paniscus lymphocryptovirus } \\
1 \text { (ApanLCV1) }\end{array}$ & BILF1 & - & - & - \\
\hline & $\begin{array}{c}\text { Pithecia pithecia } \\
\text { lymphocryptovirus } 1 \text { (Ppit LCV1) }\end{array}$ & BILF1 & - & - & - \\
\hline & $\begin{array}{c}\text { Porcine lymphotropic herpesvirus } \\
\text { 1, } 2 \text { and } 3 \text { (PLHV1-3) }\end{array}$ & BILF1 & - & - & - \\
\hline
\end{tabular}

protein kinase B (Akt), cAMP responsive element binding protein (CREB), glycogen synthase kinase 3 (GSK3), hypoxia inducible factor 1 $\alpha$ (HIF1 $\alpha$ ), Janus kinase 2 (JAK2), c-jun N-terminal kinase (JNK), lymphocyte enhancing factor (LEF), tyrosine-protein kinase (LYN), mitogen-activated protein kinase (MAPK), nuclear factor of activated T-cells (NFAT), Nuclear factor kappa B (NF- $\mathrm{kB}$ ), phosphatoinositide-3-kinase- $\gamma$ polypeptide (PI3K $\gamma$ ), protein kinase C (PKC), phospholipase C (PLC), Ras-related C3 botulinum toxin substrate 1 (RAC1), stress-activated protein kinase (SAPK), serum response factor (SRF), signal transducer and activator of transcription 3 (STAT3), T-cell factor (TCF). 


\section{Different Endocytic Pathways}

In general, endocytosis is divided into two processes: pinocytosis, by which cells take in fluid and small particles, and phagocytosis, which is performed by specialised cells that have the capacity to uptake larger particles ( $>500 \mathrm{~nm}$ ) such as microorganisms and cell debris (Figure 1). Pinocytosis is further divided into macro- and micropinocytosis. By macropinocytosis, cells take in extracellular fluid via large endocytic vesicles which are heterogeneously sized $(200-500 \mathrm{~nm})$ termed macropinosomes. In micropinocytosis, specific molecules enter the cell through smaller vesicles and can be further divided to clathrin-mediated endocytosis $(70-150 \mathrm{~nm})(\mathrm{CME})$, caveolae-mediated endocytosis $(60-80 \mathrm{~nm})$ or non-coated vesicles (Figure 1) [3,17].

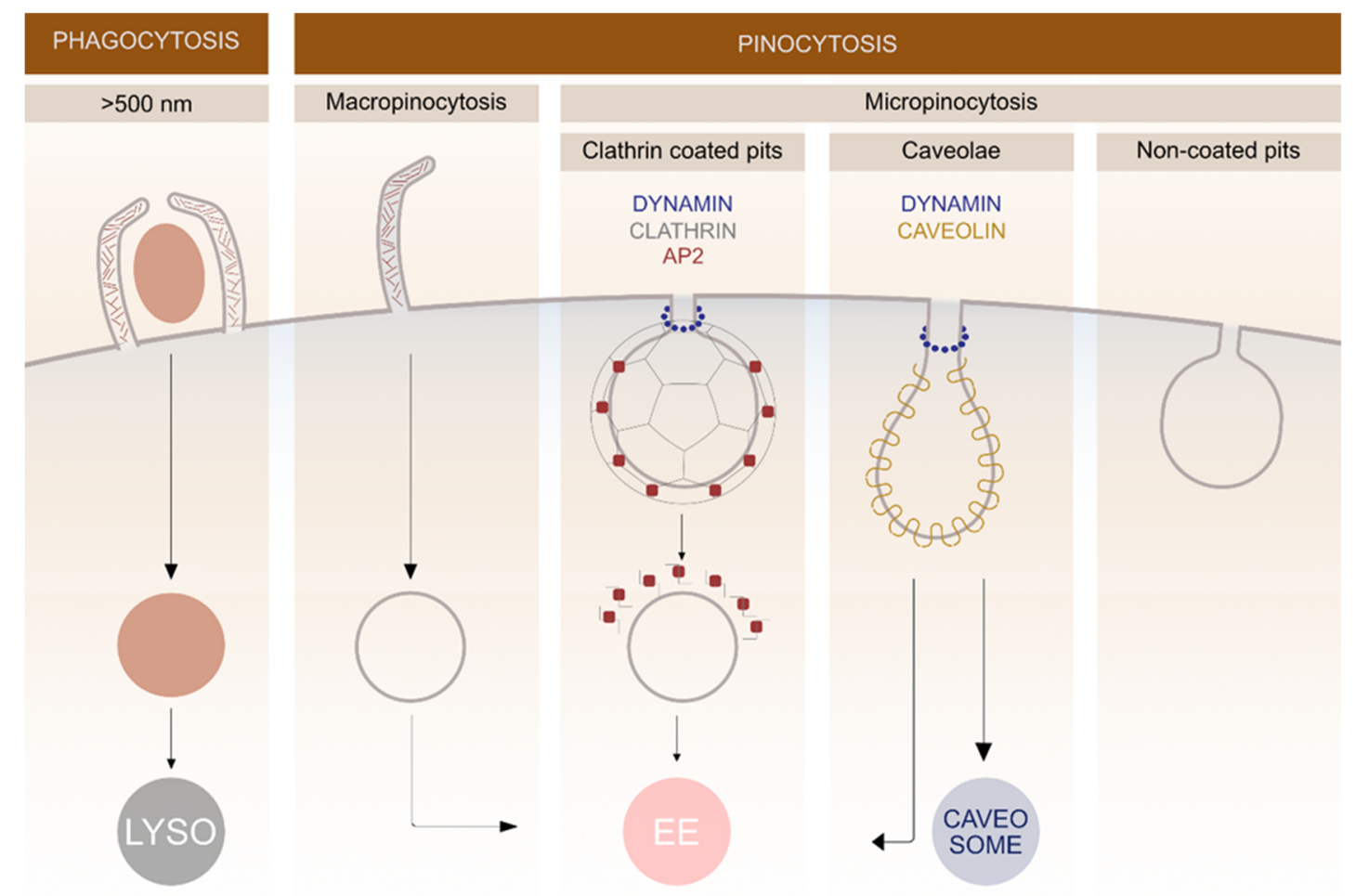

Figure 1. Schematic representation of different endocytic pathways in mammalian cells. The endocytosis is divided into various subgroups based on the size of the cargo entering the cell. Different membrane proteins are involved in clathrin and caveolin-mediated pathways and the fate of cargo molecules depends on specific endocytic mechanisms. Lysosomes (LYSO), adaptor protein 2 (AP2), early endosomes (EE).

After pinching off the PM, the majority of endocytic vesicles are fused with early endosomes where the cargo is sorted. Later, it can either recycle back to the PM or it can be directed into degradation pathways. Late endosomes are formed via fusion of early endosomes in an endosome maturation process, where the structures of membrane proteins change. After endosome maturation, the recycling to the PM stops and non-recycled material is further directed into degradation pathways [18]. Degradation takes place in lysosomes, which are formed by fusion of late endosomes and pre-existing lysosomes. During maturation, transport from the trans-Golgi network to endosomes occurs, providing newly synthesized lysosomal enzymes for the endosomes [19].

\subsection{Clathrin-Mediated Pathway}

The most extensively studied form of endocytosis is the clathrin-mediated pathway, which occurs in all mammalian cells. This pathway has traditionally been described as the most commonly used 
endocytic pathway for the majority of GPCRs [20]. Among vGPCRs, US28 and ORF74 use the clathrin-mediated pathway as one of the mechanisms for internalization, however, their mechanism for cell entry is promiscuous, as described later. A clathrin-coated vesicle forms on the PM and is coated with the protein clathrin on its cytosolic face. This plays a central role for receptor internalization and recycling, but also for the uptake of numerous important molecules such as nutrients, antigens, growth factors, and pathogens [21]. The CME is divided into the following stages: coat nucleation and assembly, coated pit maturation, fission, and uncoating [22].

The clathrin coat assembles on the cytosolic surface of the PM and is composed of different components: adaptor proteins, cargo, lipids, and clathrin [22]. Clathrin, the most important component of the coat, comprises of three clathrin heavy chains (CHC) and three clathrin light chains (CLC). Its recognisable structure is also termed triskelion. With clathrin polymerisation, a lattice-like structure forms around the vesicle. Since clathrin is unable to directly bind to the lipid and protein components of the PM, it requires adaptor proteins which link the clathrin coat with the PM and specific cargo assembled on PM [6,23].

Adaptor protein 2 (AP2) is the major adaptor protein which is bound to the membrane phosphatidylinositol. It consists of four subunits: two larger $\alpha$ and $\beta 2$ and two smaller $\mu 2$ and $\sigma 2$. Via the $\alpha$ subunit, AP2 binds to phosphatidylinositol that anchors AP2 at the PM. $\beta 2$ subunit binds the heavy chain of clathrin and therefore links clathrin to the PM. The $\mu 2$ subunit recognises specific tyrosine motifs (YXXФ; $\Phi$ represents a hydrophobic residue $(\mathrm{V}, \mathrm{I}, \mathrm{L}, \mathrm{F}, \mathrm{W}, \mathrm{Y}, \mathrm{M})$ ) on integral membrane receptors, which triggers their selective arrangement in clathrin rich areas. AP2 can bind to receptors via other adaptor proteins such as the $\beta$-arrestins which bind to the $\beta 2$ subunit of AP2 [21,24]. Binding to $\beta$-arrestins is not obligatory for receptor internalization as observed in US28 and ORF74. For US28, constitutive $\beta$-arrestin independent clathrin-mediated internalization has been described in MEF (mouse embryonic fibroblasts) cells, where both $\beta$-arrestin 1 and $\beta$-arrestin 2 were depleted [25]. For ORF74, the difference in $\beta$-arrestin recruitment was observed by comparing ligand-induced and constitutive internalization. CXCL1 and CXCL8 mediated rapid endocytosis relies on recruitment of both $\beta$-arrestin- 1 and -2 , whereas constitutive endocytosis does not require $\beta$-arrestins, comparable to US28 [26].

Epsin and eps15 are adaptor proteins with ubiquitin-interacting motifs. Therefore, they direct ubiquitin tagged cargo into clathrin-coated vesicles. Different proteins such as AP180 and CALM mediate the size of the clathrin-coated vesicle. AP180 is found in neurons and CALM is ubiquitously spread [22].

Formation of a clathrin-coated vesicle involves PM bending, which occurs under the influence of protein endofilin, amphiphysin, and epsin. Amphiphysin binds to clathrin, AP2, and dynamin [6]. Dynamin GTPases are necessary for pinching off mature clathrin-coated vesicles. After clathrin-coated vesicles enter the cell they rapidly depolymerize their clathrin coat into units under the influence of cytosolic chaperone Hsc70, which catalyses the depolymerization [21].

Specific motifs located at the C-terminal domains of transmembrane proteins determine recruitment in clathrin-coated vesicles. There are four types of motifs recognized: YXX $\Phi$ (interacts with $\mu 2$ subunit of AP2), [DE]XXXL[LI] (recognized by $\beta 2$ subunit of AP2 and $\alpha / \sigma 2$ hemicomplex), FXNPXY (interacts with $\mu 2$ subunit of AP2) and polyubiquitination (recognized by epsin and Eps15) [24,27]. In this article the internalization motifs recognized in vGPCRs US28, ORF74, and BILF1 are presented (Table 2). 
Table 2. Predicted eukaryotic linear motifs (ELM) in vGPCRs.

\begin{tabular}{|c|c|c|c|c|c|}
\hline Receptor & Elm Name & $\begin{array}{c}\text { Instances } \\
\text { (Matched Sequence) }\end{array}$ & Positions & Elm Description & Cell Compartment \\
\hline EBV-BILF1 & TRG_ENDOCYTIC_2 & YSAF & $32-35[\mathrm{~A}]$ & $\begin{array}{l}\text { Tyrosine-based sorting signal responsible } \\
\text { for the interaction with } \mu 2 \text { subunit of AP } \\
\text { (Adaptor Protein) complex }\end{array}$ & $\begin{array}{c}\text { plasma membrane, } \\
\text { clathrin-coated endocytic vesicle, } \\
\text { cytosol }\end{array}$ \\
\hline PLHV1-BILF1 & TRG_ENDOCYTIC_2 & YTTL & 179-182 [A] & $\begin{array}{l}\text { Tyrosine-based sorting signal responsible } \\
\text { for the interaction with } \mu 2 \text { subunit of AP } \\
\text { (Adaptor Protein) complex }\end{array}$ & $\begin{array}{c}\text { plasma membrane, } \\
\text { clathrin-coated endocytic vesicle, } \\
\text { cytosol }\end{array}$ \\
\hline PLHV2-BILF1 & TRG_ENDOCYTIC_2 & YAVL & 159-162 [A] & $\begin{array}{l}\text { Tyrosine-based sorting signal responsible } \\
\text { for the interaction with } \mu 2 \text { subunit of AP } \\
\text { (Adaptor Protein) complex }\end{array}$ & $\begin{array}{c}\text { plasma membrane, } \\
\text { clathrin-coated endocytic vesicle, } \\
\text { cytosol }\end{array}$ \\
\hline PLHV3-BILF1 & TRG_ENDOCYTIC_2 & YAAL & 194-197 [A] & $\begin{array}{l}\text { Tyrosine-based sorting signal responsible } \\
\text { for the interaction with } \mu 2 \text { subunit of AP } \\
\text { (Adaptor Protein) complex }\end{array}$ & $\begin{array}{c}\text { plasma membrane, } \\
\text { clathrin-coated endocytic vesicle, } \\
\text { cytosol }\end{array}$ \\
\hline US28 & TRG_ENDOCYTIC_2 & $\begin{array}{l}\text { YYAI } \\
\text { YAIV } \\
\text { YRPV } \\
\text { YDYL } \\
\text { YLEV } \\
\text { YHSM }\end{array}$ & $\begin{array}{l}130-133[\mathrm{~A}] \\
131-134[\mathrm{~A}] \\
138-141[\mathrm{~A}] \\
177-180[\mathrm{~A}] \\
179-182[\mathrm{~A}] \\
321-324[\mathrm{~A}]\end{array}$ & $\begin{array}{l}\text { Tyrosine-based sorting signal responsible } \\
\text { for the interaction with } \mu 2 \text { subunit of AP } \\
\text { (Adaptor Protein) complex }\end{array}$ & $\begin{array}{c}\text { plasma membrane, } \\
\text { clathrin-coated endocytic vesicle, } \\
\text { cytosol }\end{array}$ \\
\hline ORF74 & TRG_ENDOCYTIC_2 & YGLF & $326-329[\mathrm{~A}]$ & $\begin{array}{l}\text { Tyrosine-based sorting signal responsible } \\
\text { for the interaction with } \mu 2 \text { subunit of AP } \\
\text { (Adaptor Protein) complex }\end{array}$ & $\begin{array}{c}\text { plasma membrane, } \\
\text { clathrin-coated endocytic vesicle, } \\
\text { cytosol }\end{array}$ \\
\hline
\end{tabular}


Eukaryotic linear motifs (ELMs) are protein interaction sites important for regulation of different biological roles exploited by proteins. We investigated known endocytosis-related ELMs of six vGPCR (EBV-BILF1, PLHV1-BILF1, PLHV2-BILF1, PLHV3-BILF1, HCMV-US28, and KSHV-ORF74) using ELM resource database [28]. The obtained pattern of conserved amino acids, which is a set of sequences that can be related to molecular function, is common for all and is MVIF. Probability was also calculated for each ELM class and was same for all $(p=0.0259)$ and should reflect the probability of the regular expression to be found by chance in any given protein sequence. All six receptors encode $Y X X \Phi$ sorting signal, which interacts with the $\mu 2$ subunit of AP2 complex in clathrin-coated vesicles. This observation is in line with previously described observations for US28 and ORF74, where functional interaction with the AP2 complex was proven [25,29]. However, BILF1 receptors have not been functionally characterized yet in respect to their endocytic strategies. Based on these predicted ELMs observed for BILF1 receptors, it is our aim to test and describe routes these receptors use in endocytic trafficking.

Each of these vGPCRs were also checked for nucleotide base sequence similarities (BLAST, NCBI). EBV-BILF1, showed sequence similarities to other Herpesvirales (taxid: 548681), but no high homology outside of this taxid, indeed all returns showed herpesvirus 4. PLHV1-BILF1 again stayed within the Herpesvirales with 92.5\% homology to PLHV2, 75.59\% to PLHV3, 99.92\% PLHV1 and $100 \%$ with porcine gamma-herpesvirus envelope glycoprotein B (gpB) gene, however their query covers amounted to just $81 \%, 50 \%, 3 \%$, and $3 \%$ respectively. Hits with myotis gammaherpesvirus 8 , rhinolophus gammaherpesvirus 1 , and cricetid gammaherpesvirus 2 were also observed but with low query covers. PLHV2-BILF1 naturally had homologies with various porcine herpesvirus 2 sequences but also with PLHV3 (76.05\% with 46\% query coverage) and PLHV1 and porcine gamma-herpesvirus envelope glycoprotein B ( 93\% with just 4\% query coverage), with bovine gammaherpesvirus 6 , rhinolophus gammaherpesvirus 1, human gammaherpesvirus 8 and herpesvirus 8 type $\mathrm{M}$ all featuring on the distance tree. PLHV3-BILF1, showed similarities between lymphotropic herpesvirus 1 and 2 (98.3\% and $78.32 \%$ with query coverage of $11 \%$ and $9 \%$ respectively). Once coverage was under $3 \%$ only molossus molossus gammaherpesvirus 1 isolate and alcelaphine gammaherpesvirus 1 strains showed similarities. HCMV-US28 naturally showed similarities with the differing human herpesvirus 5 strains, whilst KSHV-ORF74 sequence similarity matches mainly came up with human herpesvirus 8, human gammaherpesvirus Kaposi's sarcoma-associated herpesvirus glycoprotein M (all of which were observed with $97-100 \%$ homology to differing sequences).

\subsection{Caveolae}

Caveolae are flat to flask shaped, 60-80 nm wide membrane pits, rich in the protein caveolin. They are enriched in certain cell types such as fibroblasts, smooth muscle cells, endothelial cells, and adipocytes and are involved in endocytosis and transcytosis as well as in calcium signalling and other signal transduction events. They are also involved in endocytosis of different pathogens [30]. Furthermore, internalization of different membrane components such as extracellular ligands, bacterial toxins and viruses (SV40, Polyoma viruses) can occur through caveolae [6]. Three types of caveolins (CAV 1, 2, 3) are important for caveolae formation. They all possess specific hairpin structures in both $\mathrm{N}$ - and C-terminus and in their long U-shaped intermembrane part. Caveolae formation with CAV 1 and 3 is closely related with lipid rafts, since these two proteins are mainly located in cholesterol, sphingolipids, and sphingomyelin rich parts of membrane. Dynamin is responsible for pinching off caveolae from the PM [30]. After entering the cell, caveolae can either fuse with early endosomes (this process depends on Rab5 protein presence), or caveosomes (this process is independent of Rab5 protein) or are recycled back onto the PM [31]. By utilizing caveolae mediated cell entry, different pathogens (bacteria, viruses) avoid degradation in lysosomes and thereby prolong their survival in cells [30]. 


\subsection{Lipid Rafts}

Lipid rafts are small (10-200 nm), mobile, heterogeneous, and detergent resistant domains enriched in cholesterol, sphingolipids, glycosylphosphatidylinositol (GPI-anchored protein), and glycosphingolipid. Lipid rafts play important roles in different aspects of cellular physiology, although specific mechanisms of their functions are still not clear [32]. It has been described that various immune receptors are translocated to lipid rafts upon their activation as a consequence of high signalling molecule concentration in these areas [33-35]. Many viruses bind to lipid rafts to initiate their further entry into the cell. They either bind to glycolipids enriched in the lipid rafts or to different viral receptors [36]. Moreover, it is also known that different bacterial toxins (Shiga toxin and Cholera toxin) and certain viruses (Polyoma virus and simian virus 40) use specific PM lipids as receptors for endocytosis [37]. It has recently been proposed that novel corona virus SARS-CoV-2 uses lipid rafts for entering into the host cell by binding ACE2 (angiotensin converting enzyme 2) which is enriched in lipid rafts, however, further studies are required [38]. It has also been suggested that viral budding of HIV can occur in lipid rafts due to their enrichment of cholesterol molecules [39].

Various lipid raft-dependent pathways have been described, with caveolae dependent endocytosis being one of them. GPI-anchored proteins, endothelin, growth factors, and glycolipids exploit lipid rafts for endocytosis [40]. A potential role of lipid rafts has also been described for US28. This receptor is enriched in detergent-resistant membrane fractions and is palmitoylated at the C-terminal end upon receptor activation. This process acts as a targeting signal that directs the receptor to caveolae. However, co-localization of US28 with caveolin was not detected indicating a raft dependent, caveolin-independent pathway for US28 [41].

\section{Endocytic Properties of The Most Commonly Studied vGPCRs}

\subsection{Cytomegalovirus (CMV)}

Cytomegalovirus is a severe virus which causes deadly infections among immunosuppressed patients [42]. Human cytomegalovirus (HCMV) open reading frames (ORF) encodes four vGPCRs: US28, US27, UL33, and UL78; the first three mimic chemokine receptor structure. Mouse and rat CMV encodes homologs of UL33 and UL78, but not US28 and US27 [12].

US28 is an extensively studied receptor that has been shown to be functionally important in various aspects of HCMV infection. It displays high constitutive (ligand independent) activity and binds a broad range of chemokines [43-45]. It is the first vGPCR used as an antiviral drug target to selectively kill HCMV infected cells using fusion toxin protein [46-48]. This strategy relies on the ability of this receptor to internalize constitutively and thereby deliver the immunotoxin intracellularly [25,47]. The majority of US28 receptors is located intracellularly in endosomes in the perinuclear region with only a small amount located in the PM (Figure 2). It was revealed that constitutive endocytosis is $\beta$-arrestin independent; nevertheless, it still employs a pathway through clathrin-coated vesicles as shown in embryonic fibroblasts acquired from $\beta$-arrestin- 1 and -2 knockout mice using siRNA against the $\mu 2$ subunit of AP-2 adaptor protein [25]. When comparing the endocytosis of US28 in the control and $\beta$-arrestin knockout cells, no differences were observed [25]. 


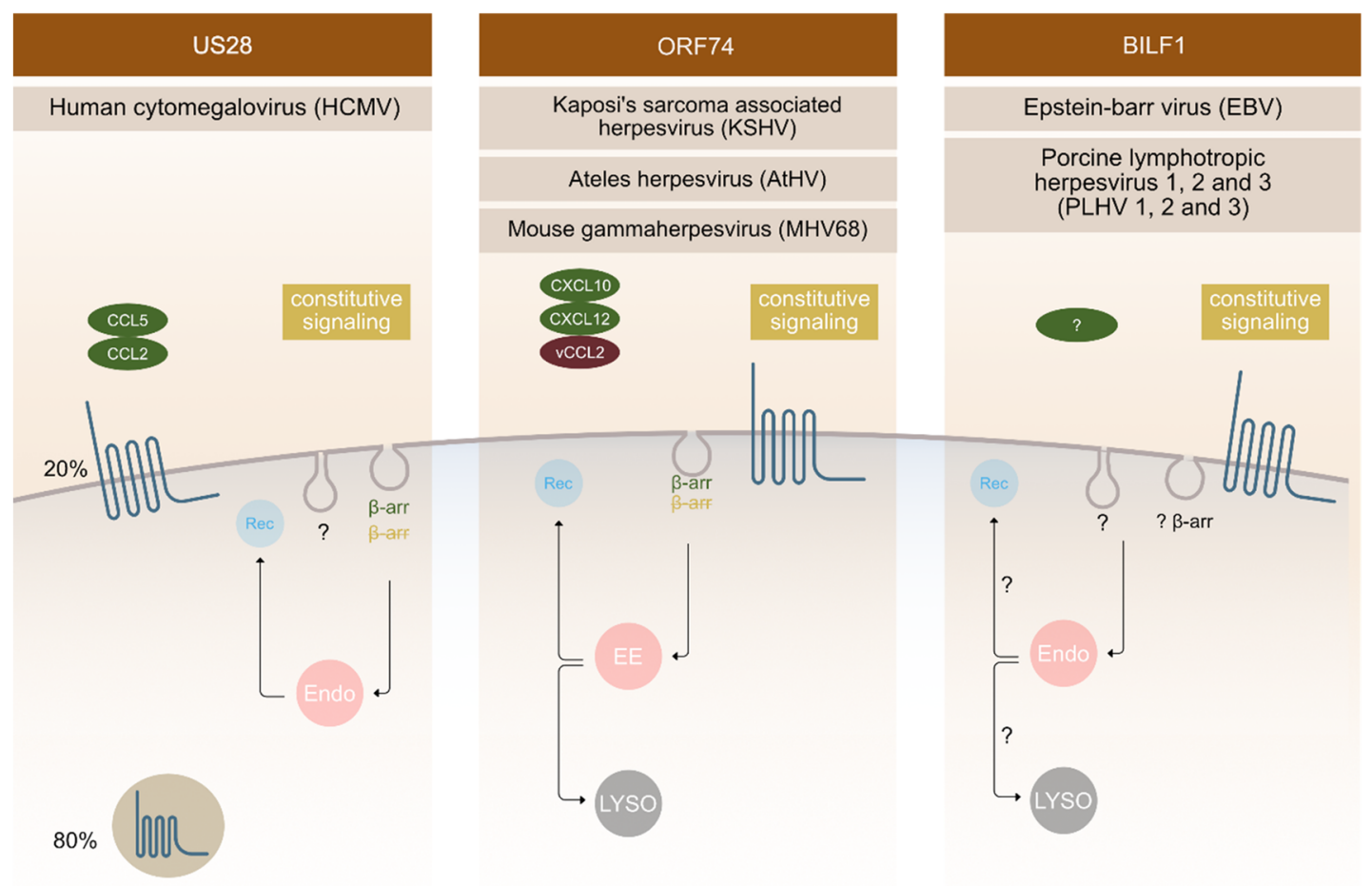

Figure 2. Endocytic mechanisms employed by vGPCRs. Different vGPCRs use different mechanisms to enter the cell. Besides ligand dependent endocytosis (as shown on the Figure for US28 with ligands CCL5 and CCL2 and for ORF74 with ligands CXCL10, CXCL 12 and VCCL2), constitutive (ligand independent) endocytosis is a common feature observed for these receptors. The fate of receptors inside the cell is tightly regulated and has an important impact on receptor function outcome. Localization of vGPCRs differs, with ORF74 and BILF1 receptors predominantly localizing at the surface and US28 localizing intracellularly in $80 \%$ and at the surface at $20 \%$. Endosomes (endo), recycling (Rec), $\beta$-arrestin ( $\beta$-arr), early endosomes (EE), lysosomes (LYSO).

It is assumed that US28 internalization could partially use caveolae or lipid rafts, since palmitoylation of US28 has been observed. Palmitoylation is a step in the receptor activation process and serves as a targeting signal for receptors to caveolae [41]. Typically, after ligand-mediated receptor activation, the C-terminal tail is phosphorylated, which eventually leads to $\beta$-arrestin binding and endocytosis. The C-terminal tail of US28 receptor contains many serine and threonine residues which represent potential phosphorylation sites. Research shows that the C-terminal end is constitutively phosphorylated, therefore it enables the constitutive activity of receptors [25].

Similar to US28, US27 and UL33 (HCMV) are located intracellularly. The intracellular localization of UL33 was however only observed in HeLa and COS-7 cells, but not in HEK-293, where the receptor was mostly located at the PM. This suggests that the receptor localization is cell type specific. Co-localization of US27-YFP/UL33-GFP with LAMP1, the marker of late endosomes/lysosomes, was shown in Hela cells, which indicates that these receptors are located in late endocytic compartments [49]. It is believed that localization within these compartments enables US28, US27, and UL33 to bud into a viral membrane when the virus is exiting the cell [49]. Immunohistochemistry on cryosections showed that UL33 is located at multivesicular bodies (MVB), but it is still unknown whether UL33 can recycle back to the PM or it enters a degradation pathway through lysosomes [49].

When co-expressing US27 and US28, colocalization was observed, suggesting that both proteins are located in late endosomes/lysosomes. Based on this overlap, it was examined whether US27 is similarly internalized and revealed that a large amount of this receptor is found in intracellular vesicles, indicating receptor internalization in a constitutive manner, like for US28 [49]. 
Little is known about UL78. It is believed, that this receptor is not necessary for viral replication in cell cultures, but its function in vivo remains to be studied [49]. This receptor is mainly localized within the cytoplasm of the endoplasmatic reticulum, although surface expression has also been proposed. Furthermore, it has been shown that UL78 undergoes constitutive endocytosis and recycling back to PM [50].

\subsection{Kaposi's Sarcoma Associated Herpesvirus (KSHV)}

The ORF74 receptor family is encoded by $\gamma$ 2-herpesviruses, such as: KSHV, MHV68, HVS, AtHV, and EHV2. They bind CXC chemokines, and most often also display constitutive activity. ORF74 encoded by KSHV is the most thoroughly characterized receptor in this group, followed by ECRF3 from HVS. Both bind CXC-chemokines; KSHV-ORF74- with a broader spectrum compared to ECRF3-HVS [51-55]. The constitutive signalling of KSHV-ORF74-has been directly linked to tumorigenesis in several mouse models [56-58]. In terms of cellular localization, KSHV-ORF74- has been described to be mostly located at the PM (Figure 2), but also to undergo internalization.

CXCL1-, and CXCL8-mediated endocytosis was shown to depend on $\beta$-arrestin 1 and 2, whereas the constitutive endocytosis occurs independently of $\beta$-arrestin [26]. The AP-2 complex plays an important role in constitutive internalization of ORF74 (Figure 2). This adaptor complex is also important for clathrin-coated vesicles mediated endocytosis [29]. After internalization, the receptor is found in early endosomes, and from there it recycles back at the PM or it fuses with lysosomes and enters the degradation pathway [59].

\subsection{Epstein-Barr Virus (EBV) and Its Closely Related Lymphocryptoviruses}

The first BILF1 receptors were recognized as GPCR's in 2005 [60]. They are encoded by different $\gamma$-1-herpesviruses (EBV, other primate lymphocryptoviruses, porcine lymphotropic herpesviruses (PLHV1, 2, 3) and other ungulate gammaherpesviruses) [61-63]. The sequence identity of BILF1 receptors varies, with ape $\gamma-1$ herpesvirus BILFs being highly conserved and ungulate $\gamma-1$ herpesvirus BILFs being more distantly related [63]. However, ORF encoding BILF1 receptors was described for all above mentioned $\gamma-1$ herpesviruses at a similar genomic position [64-66]. Functionally, EBV-BILF1 remains the most studied among BILF1 receptors until this day. It is an orphan receptor with well-established constitutive signalling and internalization properties. Confocal microscopy has shown that EBV-BILF1, similar to KSHV-ORF74-, predominantly locates at the cell surface, but there is a difference among BILF1 orthologs of this family $[60,63]$. Studies of BILF1 receptors from different primate lymphocryptoviruses showed that BILF1 receptor encoded in PtroLCV1 (lymphocryptovirus from chimpanzee) and PpygLCV1 (Lymphocryptovirus from orangutan) predominantly locates intracellularly and not at the PM. It was therefore shown that localization is not preserved among the family [63]. However, EBV-BILF1 has been shown to internalize in a constitutive manner [63], a cellular phenomenon that seems linked to the main function of BILF1 as a MHC-1 downregulating molecule [15]. This immunevasive property has also been confirmed for RhLCV-BILF1, but not for CalHV3-BILF1 $[15,67]$. Further investigation on BILF1 mediated endocytic routes is therefore needed in order to fully understand its functional properties.

\section{Methodological Approaches and Novel Techniques to Study Receptor Mediated Endocytosis}

GPCR internalization studies are carried out using different methods. The majority of these use the receptor linked with specific epitopes (HA, FLAG-tag, SNAP-tag, CLIP-tag), which enables binding of specific antibodies and therefore receptor detection in cell [68]. 


\subsection{Real-Time Internalization Assay}

To study the dynamics of internalization and recycling in real-time, a novel method based on time-resolved fluorescence resonance energy transfer (TR-FRET) is used (Figure 3). This method uses an N-terminal receptor tag (called SNAP-tag), a $20 \mathrm{kDa}$ mutant of the DNA repair protein O6-alkylguanine-DNA alkyl transferase. It has no restrictions regarding cellular localization and expression in different cell lines. SNAP-tag is labelled with a tag-lite ${ }^{\circledR}$ SNAP Lumi4 ${ }^{\circledR}$-Tb substrate (donor), a cell impermeable substrate chemically inert towards other proteins. After one-hour labelling, the donor is washed off and fluorescein (acceptor) is added to the cells. During the measurement, excitation of the donor causes the energy transfer to acceptor resulting in quenching of the donor emission [69].

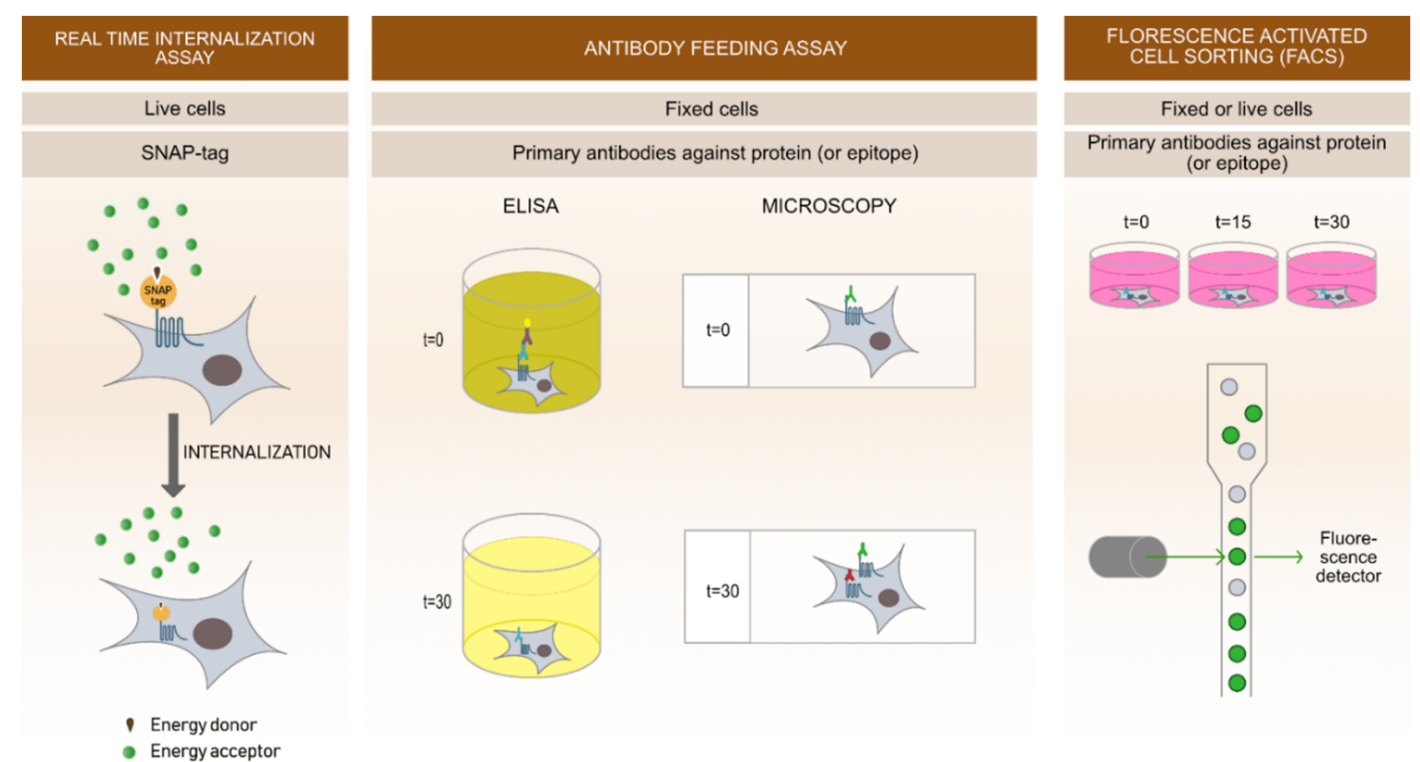

Figure 3. Methods to study GPCR internalization. Different approaches can be used for receptor internalization analysis.

With this method, agonist-induced and constitutive internalization can be followed in real-time (Figures 3 and 4). To obtain the best detection of constitutive internalization, labelling of surface receptors with tag-lite ${ }^{\circledR}$ SNAP Lumi $4^{\circledR}-\mathrm{Tb}$ must be performed at $4{ }^{\circ} \mathrm{C}$ to prevent endocytosis during the labelling process. Further, to allow for receptor internalization; measurements are performed at $37^{\circ} \mathrm{C}$. When observing agonist-induced internalization, labelling is usually performed at $37^{\circ} \mathrm{C}$, since the internalization is later triggered by addition of the agonist [69]. This novel sensitive method offers cost effective, fast, high throughput approaches to study ligand-induced or constitutive receptor internalization kinetics. Its limitation is the use of relatively large SNAP-tag on receptors, which could potentially change receptor localization and signalling patterns. Therefore, an additional comparison of SNAP-tagged and WT receptor, as for example receptor signalling, is needed prior the assay. 
(a)

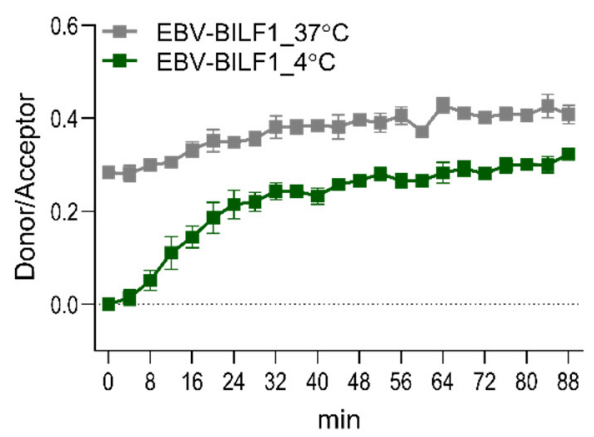

(c)

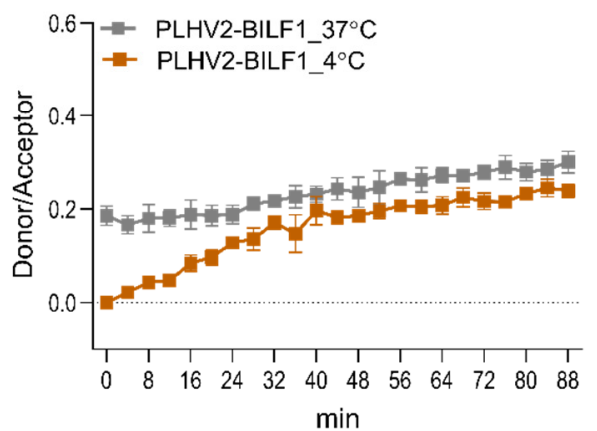

(b)

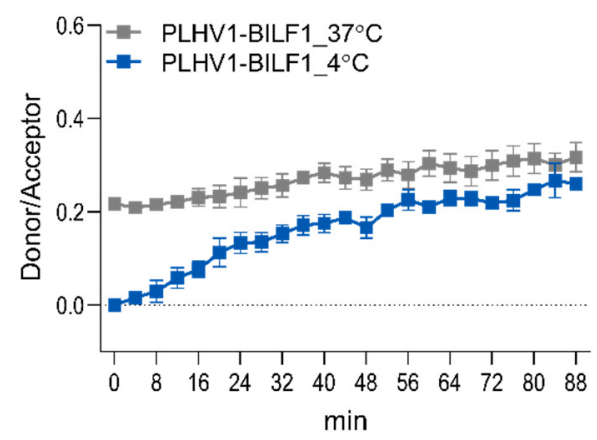

(d)

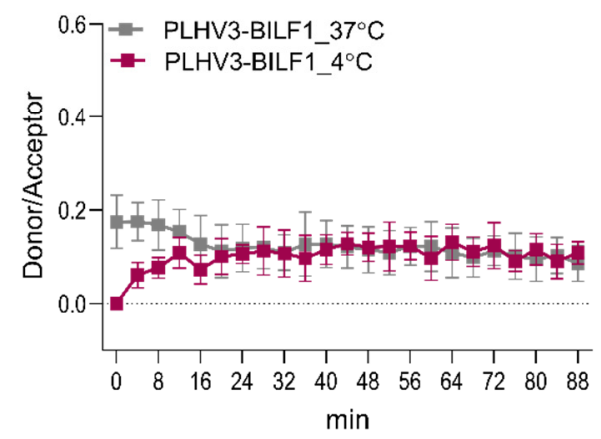

Figure 4. BILF1 receptors internalize constitutively. HEK293A cells were transfected with (a) SNAP-EBVBILF1, (b) PLHV1-BILF1, (c) PLHV2-BILF1, and (d) PLHV3-BILF1. Donor labelling was performed at $4{ }^{\circ} \mathrm{C}$ (coloured curves) and $37^{\circ} \mathrm{C}$ (grey curves). Graphs represent means \pm SEM of two individual experiments performed in triplicate.

As an example of this technique applied for the vGPCRs, we SNAP-tagged EBV-BILF1 and the three porcine herpesvirus-encoded (PLHV1-3) BILF1 receptors and determined constitutive internalization of all four receptors (Figure 4). For receptors, labelled with the donor molecule at $37^{\circ} \mathrm{C}$, only a small increase in internalization was observed. This is mainly because the labelled receptors had already reached an equilibrium of the internalization/recycling process during the labelling period. Therefore, we performed the labelling of receptor at $4{ }^{\circ} \mathrm{C}$ to prevent any constitutive internalization in this period. With this approach, the internalization was increased.

\subsection{Antibody Feeding Assay}

Antibody feeding allows determination of receptor endocytosis at different time points on fixated cells. In principle, studied receptors must be specifically labelled with antibodies that recognize specific epitopes on the $\mathrm{N}$-terminal site of the receptors. Use of recombinant receptors tagged with engineered extracellular tags (for example FLAG, HA, Myc) are very common and specific antibodies against these tags are commercially available.

Antibody feeding can be performed using two different principles. With ELISA assays, one of the most useful methods for determination of receptor surface expression, the amount of surface expressed receptors can be quantitatively assessed over time. Secondly, using a microscopy approach, surface expression, and internalized receptors, they can be visualized in different time points after induction of internalization. Internalization can be induced by ligands targeting the studied receptors or in case of constitutively active receptors by inducing a temperature shift. Thereby, it is possible to prevent internalization by cooling the cells (incubation at $4{ }^{\circ} \mathrm{C}$ ) and induce internalization by incubating the cells at temperatures of $18^{\circ} \mathrm{C}$ or higher (usually $37^{\circ} \mathrm{C}$ ). 
In both principles, initial incubation with specific primary antibodies at $4{ }^{\circ} \mathrm{C}$ prevents internalization processes and allows labelling of only surface expressed receptors. Afterwards, cells are incubated at $37^{\circ} \mathrm{C}$ (with or without the ligand) for various time points, allowing the receptors to internalize. Following internalization, cells are fixed and in case of ELISA stained with horseradish peroxidase-conjugated secondary antibodies. In the presence of horseradish peroxidase substrate, secondary antibody gives a reaction of the supernatant and its optical density (OD) can be measured with ELISA plate readers. By this we can determine the amount of the receptors expressed at the cell surface in different time points quantitatively.

Performing microscopy experiments, incubation at $37^{\circ} \mathrm{C}$ and additional fixation is followed by labelling with the first secondary antibody labelled with a specific fluorophore (for example Alexa 488) that visualizes labelled receptors at the cell surface. Cells are then additionally permeabilized and incubated with another secondary antibody (for example Alexa 647 antibodies) that labels internalized receptors and unlabelled receptors at the cell surface. This way, we can differentiate between the amount of surface remaining receptors and internalized receptors [68-70]. Antibody feeding assays provide direct visualisation of receptor internalization at specific time points. Despite these benefits, the procedures require a few washing steps and temperature shifts, which can affect cell morphology and viability.

Antibody feeding has been used to determine constitutive internalization of EBV-BILF1, PtroLCV1-BILF1, PpygLCV1-BILF1, and SsynLCV1-BILF1 where all described receptors localized into intracellular compartments after $30 \mathrm{~min}$ [63]. Further, for US28, both internalization and recycling were confirmed by antibody feeding assay using microscopy approach. In the case of recycling, after incubation with the first antibody, cells were washed and additionally re-incubated with another antibody for $1 \mathrm{~h}$ at $37^{\circ} \mathrm{C}$. Receptors that recycled to the cell surface were stained with the secondary antibody and internalized again [71].

\subsection{Fluorescence-Activate Cell Sorting (FACS)}

FACS can quantitatively determine the decrease of receptors expressed at the cell surface after ligand addition or in case of constitutive internalization by a temperature shift. Receptors can be detected in several different ways. Similar to ELISA, receptors can be labelled by N-terminal epitope-tags and subsequently incubated with specific primary antibodies directly conjugated with a fluorescent dye. Receptors can also be tagged with a fluorescent tag (for example GFP). Changes in surface expression of the receptor can be measured in different time points. With this method, receptor internalization and recycling rates can be estimated accurately, as it allows the measurement of properties on a single cell in solution [72,73].

\subsection{Microscopy Based Approaches}

Currently, fluorescence microscopy is important and represents a constantly evolving tool in the field of bioscience. When studying receptor trafficking, an initial determination of receptor cellular localization is needed. To determine GPCR localization, fluorescence microscopy is usually used. Receptors can be either stained with a fluorescent antibody against a specific tag or tagged with intrinsically fluorescent protein (green fluorescent protein (GFP)). With confocal microscopy, we can collect serial optical sections from thick specimens at around $300 \mathrm{~nm}$ resolution, which enables us to determine receptor localization in the cell with good precision. To observe internalization, antibody feeding approaches can be used (as discussed above).

One of the leading approaches in the field of single-molecule fluorescence microscopy is TIRF (Total Internal Reflection Fluorescence). TIRF is especially useful for visualization of molecules at the cell surface, making it ideal for studying GPCRs. It requires the use of fluorophore tags (eGFP, SEP or SNAP) that might disrupt general properties of wild type receptors, therefore functional analysis of tagged receptors is crucial [74-76]. 
For confocal microscopy, more than only one type of antibody can be used in a single assay, enabling us to determine co-localization of different receptors and/or proteins [72]. As a marker for recycling endosomes, antibodies against the transferrin receptor are used; for endosomes/lysosomes, antibodies against LAMP1 or CD63 are used as exemplified by studies on US28, US27, and UL33. US28 co-localized with markers for recycling endosomes and late endosomes/lysosomes, whereas US27 and UL33 significantly co-localized with markers for late endosomes/lysosomes but not with markers for recycling endosomes [49,71]. The Golgi network is marked with antibodies against $\gamma$ subunit or adaptor complex 1 [49]. For colocalization with the endoplasmic reticulum (ER), the marker calnexin is commonly used. Rab proteins are specific markers of the endocytic route. Different proteins mark different intracellular organelles which play roles in endocytosis. Rab5 is a marker for early endosomes and is a very important protein in the first step of endocytosis. Rab4 and Rab11 are linked to the recycling process, whereas Rab4 also mediates fast and direct recycling to the PM whilst Rab11 mediates slow recycling from recycling endosomes, usually located in the perinuclear region. Rab7 is a marker for late endosomes/lysosomes. It marks the degradation pathway [77].

\subsection{Manipulation of Endocytic Pathways}

\subsubsection{Chemical Inhibitors}

To better understand different types of endocytosis, researchers have developed different methods to block these processes. By using these pathway inhibitors, it is possible to assess which cell structures are responsible for certain type of endocytosis. Different pharmacological agents can represent good tools for cell manipulation with their direct inhibition of specific processes. Disadvantages are non-specificity and their ability to interfere with other cell processes [78]. CME is blocked by decreased cytosolic $\mathrm{pH}$, which restrain clathrin vesicles on the PM and disables their removal from the PM [68].

Monodansylcadaverine (MDC) is a tissue transglutaminase inhibitor that participates in clathrin assembly and internalization [68]. Hypertonic sucrose is the most widely used agent, which prevents $\mathrm{CME}$, causing cell shrinkage. It is believed that sucrose also affects endocytosis by caveolae, therefore it is a non-specific endocytic blocker. With potassium depletion, clathrin aggregation occurs in the cytoplasm, which prevents its accumulation on PMs. Chlorpromazine mediates the accumulation of adaptor proteins and clathrin on endosomal membranes, thus preventing the assembly of these proteins on PMs [79]. It also prevents the receptor recycling back to the PM in different endocytic pathways [78]. Pitstop2 is a novel transferrin inhibitor, which interrupts binding between terminal domain of clathrin and amphiphysin [68]. Temperature is another factor influencing endocytosis. CME is blocked under $16^{\circ} \mathrm{C}$ for example [78].

Regarding the fact that caveolae mediated endocytosis occurs on lipid rafts, cholesterol depletion in the PM blocks caveolae formation [68]. Cyclodextrins are used for this purpose, but besides their influence on endocytic routes, they also change the membrane structure, therefore influencing different endocytic pathways. As an alternative, filipin can be used. By binding to cell surface cholesterol, it prevents the biding of other molecules, but is cytotoxic in higher quantities [78]. Dynamin is important in both clathrin-mediated and caveolae-mediated endocytosis. At the membrane, it pinches-off newly formed vesicles and allows them to release from the surface. Dynasore has been recently described as a chemical inhibitor of dynamin and can be used for manipulation of both clathrin and caveolin-mediated endocytosis [80].

\subsubsection{Genetic Manipulation}

To avoid nonspecific effects of chemical inhibitors, different genetic approaches have been developed for endocytic inhibition. These approaches alter the expression of proteins, important for normal receptor endocytosis and includes knockout models, overexpression of dominant negative mutants and protein silencing with siRNA. 
The best way to determine a role of a specific protein is gene inactivation. There are plenty of different knockout mouse models available, lacking expression of different proteins [81]. For the purpose of endocytic studies, mouse embryonic fibroblasts (MEF) from $\beta$-arrestin knockout mice ( $\beta$ arr $1 / 2-\mathrm{KO}$ cells) are widely used, to determine whether endocytosis is $\beta$-arrestin dependent as exemplified for US28 [82].

CRISPR-cas9 (clustered regulatory interspaced palindromic repeats) is a novel method used for gene knockout. This mechanism is a defence mechanism against viruses and other invaders used by prokaryotes. Its simplicity was exploited for use in mammalian cells for the purpose of genome editing. Two components are involved in this mechanism: Cas9 protein, an enzyme which cuts DNA and sgRNA, which determines the site of cutting. SgRNA needs to be complementary to the cutting site [83]. CRISPR/Cas9 system was used to prepare dynamin- 1 and $\beta$-arrestin knockout cells. They used these cells to evaluate if the absence of these proteins influences endocytosis. Dynamin-1 is an important component, participating in vesicle scission. In its absence clathrin- and caveolin-mediated endocytosis is disabled. For this purpose, $20 \mathrm{bp}$ dynamin sgRNA was created and cloned into vector along with Cas9n. Transfection was used to introduce the vector to the cell. Dynamin-1 expression was later checked with western blot [84].

Downregulation of protein expression and therefore inhibition of specific types of endocytosis can be performed using dominant negative mutants and siRNA constructs. Dominant negative mutants of dynamin (Dyn1 K44A) [85], $\beta$-arrestin ( $\beta$-arrestin 319-418) [86], caveolin (Cav1 S80E) [87], eps15 (Eps15 $\Delta 95 / 295$ ) [88], and epsin (Epsin 1 1 UIM) [89] are widely used in different studies determining the endocytic pathway. Cav1 S80E, $\beta$-arrestin 319-418 and Dyn K44A dominant mutants have previously been used to determine endocytic properties of other GPCRs (e.g., NK1R) [90]. Overexpression of these mutants in cells masks the wild type protein function, but its function is never completely silenced. Also, it was proposed that overexpression of dominant negative mutants may cause other indirect effects in the cell, leading to misinterpreted results [78].

For silencing protein expression, siRNA constructs against different endocytic players are used. To inhibit the clathrin-mediated pathway, siRNA construct against $\mu 2$ subunit of AP2 protein was used in US28 stably transfected Hela cells [25]. Silencing the expression of this protein clearly indicated the requirement for $\mu 2$-adaptin subunit and therefore CME in US28. However, the time taken to inhibit the expression of these proteins is long (3-7 days). During this time cells can adjust to protein deficiency or can also change the expression of other genes [78].

Morpholino oligomers/morpholino antisense oligonucleotides (MO) have also been used to understand knockdown effects of GPCRs. They are generally the most widely used anti-sense knockdown tool in zebrafish and are also commonly used in other models such as chick embryos and frogs [91]. Inhibition of gene expression is undertaken via blocking translation or splice blocking, preventing assembly of the spliceosome. Although this technology is relatively inexpensive, differing knockdown yields and off-target effects are always a consideration. The use of standard control $\mathrm{MO}$, knockdown rescue experiments and use of several different knockdown MOs can help decipher potential off-target reactions and even increase knockdown levels as differing MOs are used; however, these are time consuming [92]. GPCRs and regulators ranging from gpr161 through to $\beta$-arrestin have been knocked down using this technology [93,94].

Naturally, there are also increasing amounts of data pertaining to genetic mutation/variation from published experiments in cell lines through to patients. Whilst the original intention of this work may not directly look at GPCRs, a range of bioinformatics tools means that the data can be analysed in relation to several lines of enquiry. Data from gene expression studies, biological responses, clinical findings, and outcomes data can all be combined, and networks and biomarkers may well be observed from these studies in relation to GPCRs or factors associated with them. Therefore, data mining and the large range of genomics/bioinformatics tools now available provide an invaluable resource. 


\section{Conclusions}

GPCRs play important roles in virus life cycle from the primary infection, replication, and latency establishment to various pathological outcomes. In this respect, understanding molecular and cellular behavior is of huge importance. This review has focused on three thoroughly studied vGPCRs (HCMV-US28, KSHV-ORF74, and EBV-BILF1 and homologs of these) in terms of endocytic properties as well as novel methods used for characterization of endocytic properties. Despite their distant genetic relationships, US28, ORF74, and BILF1 receptors have been linked to the development of cancer. ORF74 was described as the driver of KSHV-related malignancies inducing angiogenesis, cellular transformation, and inflammation [56,58,95]. HCMV-US28 has been detected in glioblastoma and colorectal cancers and is described as an onco-modulator constitutively upregulating angiogenesis and proliferation $[96,97]$. For BILF1, constitutive $\mathrm{G} \alpha_{\mathrm{i}}$ dependent signaling has been linked to EBV-mediated cell transformation ability both in vitro and in vivo [98]. The involvement of all three receptor classes in tumor development makes them attractive drug targets for the treatment of virus-related cancers. As shown for US28, one potential strategy to target infected cells is the use of fusion toxin protein (FTP) to specifically target and kill HCMV infected cells [46-48]. For US28, a predominantly intracellular localization pattern was described as a consequence of a rapid constitutive endocytosis [49,99]. This ability was used for the delivery of the toxin intracellularly. For US28, $\beta$-arrestin independent, constitutive CME has been shown. This is additionally supported by observations that US28 expresses a YXXФ motif known to interact with AP-2, a protein important for clathrin coat assembly. A similar motif was observed in BILF1 receptors from EBV and PLHV1-3, as well as KSHV-ORF74. BILF1 has recently been described as an immunevasive protein playing a role in downregulating surface expressed MHC class I molecules [15]. With its cell surface localization, BILF1 has been proposed to bind MHC class I molecules and internalize in complex leading to its degradation in lysosomes. BILF1 receptors are a subject of current research interest and further studies into their endocytic properties are currently ongoing and essential in order to further our knowledge.

Given the close link between signaling and internalization, and for both of these phenomenon a close link to the pathophysiology of the viruses, future studies of the internalization properties of these receptors are needed to finally establish how, when, and where to target them from a therapeutic point of view.

Author Contributions: Conceptualization, V.K. and M.M.; Methodology, M.M., K.S., Investigation, M.M.; K.S., V.K. Resources, M.M., M.M.R., M.V. Writing-Review \& Editing, V.K., M.M., C.S.R., K.S., M.M.R., and M.V.; Visualization, M.M.; Project Administration, V.K. and M.M. All authors have read and agreed to the published version of the manuscript.

Funding: This research was funded by the Slovenian Research Agency Programme (P4-0053) and PhD funding for M.Mavri. This work was also supported by a Short-term scientific mission (STSM) grant from COST Action CA 18133 (ERNEST). Authors participate in the European COST Action CA 18133 (ERNEST).

Acknowledgments: The authors would acknowledge above mentioned funding. M.M., M.M.R., K.S., V.K. and M.V., participate in the European COST Action CA 18133 (ERNEST).

Conflicts of Interest: The authors declare no conflict of interest.

\section{References}

1. Hanyaloglu, A.C.; von Zastrow, M. Regulation of GPCRs by endocytic membrane trafficking and its potential implications. Annu. Rev. Pharm. Toxicol. 2008, 48, 537-568. [CrossRef] [PubMed]

2. Joseph, J.G.; Liu, A.P. Mechanical Regulation of Endocytosis: New Insights and Recent Advances. Adv. Biosyst. 2020, 4, e1900278. [CrossRef] [PubMed]

3. Sigismund, S.; Confalonieri, S.; Ciliberto, A.; Polo, S.; Scita, G.; Di Fiore, P.P. Endocytosis and signaling: Cell logistics shape the eukaryotic cell plan. Physiol. Rev. 2012, 92, 273-366. [CrossRef] [PubMed]

4. Barbieri, E.; Di Fiore, P.P.; Sigismund, S. Endocytic control of signaling at the plasma membrane. Curr. Opin. Cell Biol. 2016, 39, 21-27. [CrossRef] 
5. Lobingier, B.T.; von Zastrow, M. When trafficking and signaling mix: How subcellular location shapes G protein-coupled receptor activation of heterotrimeric $G$ proteins. Traffic 2019, 20, 130-136. [CrossRef]

6. Kumari, S.; Mg, S.; Mayor, S. Endocytosis unplugged: Multiple ways to enter the cell. Cell Res. 2010, 20, 256. [CrossRef]

7. Hanyaloglu, A.C. Advances in Membrane Trafficking and Endosomal Signaling of G Protein-Coupled Receptors. Int. Rev. Cell Mol. Biol. 2018, 339, 93-131. [CrossRef]

8. Sobhy, H. A comparative review of viral entry and attachment during large and giant dsDNA virus infections. Arch. Virol. 2017, 162, 3567-3585. [CrossRef]

9. Traylen, C.M.; Patel, H.R.; Fondaw, W.; Mahatme, S.; Williams, J.F.; Walker, L.R.; Dyson, O.F.; Arce, S.; Akula, S.M. Virus reactivation: A panoramic view in human infections. Future Virol. 2011, 6, 451-463. [CrossRef]

10. Alcami, A.; Lira, S.A. Modulation of chemokine activity by viruses. Curr. Opin. Immunol. 2010, $22,482-487$. [CrossRef]

11. Raftery, M.; Muller, A.; Schonrich, G. Herpesvirus homologues of cellular genes. Virus Genes 2000, 21, 65-75. [CrossRef] [PubMed]

12. Rosenkilde, M.M.; Smit, M.J.; Waldhoer, M. Structure, function and physiological consequences of virally encoded chemokine seven transmembrane receptors. Br. J. Pharm. 2008, 153 (Suppl. 1), S154-S166. [CrossRef] [PubMed]

13. Van Senten, J.R.; Fan, T.S.; Siderius, M.; Smit, M.J. Viral G Protein-Coupled Receptors as Modulators of Cancer Hallmarks. Pharmacol. Res. 2020. [CrossRef] [PubMed]

14. Vischer, H.F.; Siderius, M.; Leurs, R.; Smit, M.J. Herpesvirus-encoded GPCRs: Neglected players in inflammatory and proliferative diseases? Nat. Rev. Drug Discov. 2014, 13, 123-139. [CrossRef]

15. Zuo, J.; Currin, A.; Griffin, B.D.; Shannon-Lowe, C.; Thomas, W.A.; Ressing, M.E.; Wiertz, E.J.; Rowe, M. The Epstein-Barr virus G-protein-coupled receptor contributes to immune evasion by targeting MHC class I molecules for degradation. PLoS Pathog. 2009, 5, e1000255. [CrossRef] [PubMed]

16. Rosenkilde, M.M. Virus-encoded chemokine receptors-Putative novel antiviral drug targets. Neuropharmacology 2005, 48, 1-13. [CrossRef]

17. Weeratunga, S.; Paul, B.; Collins, B.M. Recognising the signals for endosomal trafficking. Curr. Opin. Cell Biol. 2020, 65, 17-27. [CrossRef]

18. McNally, K.E.; Cullen, P.J. Endosomal Retrieval of Cargo: Retromer Is Not Alone. Trends. Cell Biol. 2018, 28, 807-822. [CrossRef]

19. Huotari, J.; Helenius, A. Endosome maturation. EMBO J. 2011, 30, 3481-3500. [CrossRef]

20. Wolfe, B.L.; Trejo, J. Clathrin-dependent mechanisms of G protein-coupled receptor endocytosis. Traffic 2007, 8, 462-470. [CrossRef]

21. Smith, S.M.; Michael, B.; Mary, H.; Corinne, J.M. Weak Molecular Interactions in Clathrin-Mediated Endocytosis. Front. Mol. Biol. 2018. [CrossRef] [PubMed]

22. Takei, K.; Haucke, V. Clathrin-mediated endocytosis: Membrane factors pull the trigger. Trends Cell Biol. 2001, 11, 385-391. [CrossRef]

23. Kaksonen, M.; Roux, A. Mechanisms of clathrin-mediated endocytosis. Nat. Rev. Mol. Cell Biol. 2018, 19, 313-326. [CrossRef] [PubMed]

24. Mettlen, M.; Chen, P.H.; Srinivasan, S.; Danuser, G.; Schmid, S.L. Regulation of Clathrin-Mediated Endocytosis. Annu. Rev. Biochem. 2018, 87, 871-896. [CrossRef] [PubMed]

25. Fraile-Ramos, A.; Kohout, T.A.; Waldhoer, M.; Marsh, M. Endocytosis of the viral chemokine receptor US28 does not require beta-arrestins but is dependent on the clathrin-mediated pathway. Traffic 2003, 4, 243-253. [CrossRef] [PubMed]

26. De Munnik, S.M.; Kooistra, A.J.; van Offenbeek, J.; Nijmeijer, S.; de Graaf, C.; Smit, M.J.; Leurs, R.; Vischer, H.F. The Viral G Protein-Coupled Receptor ORF74 Hijacks $\beta$-Arrestins for Endocytic Trafficking in Response to Human Chemokines. PLoS ONE 2015, 10, e0124486. [CrossRef] [PubMed]

27. Ungewickell, E.J.; Hinrichsen, L. Endocytosis: Clathrin-mediated membrane budding. Curr. Opin Cell Biol. 2007, 19, 417-425. [CrossRef]

28. Kumar, M.; Gouw, M.; Michael, S.; Sámano-Sánchez, H.; Pancsa, R.; Glavina, J.; Diakogianni, A.; Valverde, J.A.; Bukirova, D.; Čalyševa, J.; et al. ELM-the eukaryotic linear motif resource in 2020. Nucleic Acids Res. 2020, 48, D296-D306. [CrossRef] 
29. Azzi, S.; Smith, S.S.; Dwyer, J.; Leclair, H.M.; Alexia, C.; Hebda, J.K.; Dupin, N.; Bidère, N.; Gavard, J. YGLF motif in the Kaposi sarcoma herpes virus G-protein-coupled receptor adjusts NF- $\mathrm{B}$ activation and paracrine actions. Oncogene 2014, 33, 5609-5618. [CrossRef]

30. Parton, R.G.; Simons, K. The multiple faces of caveolae. Nat. Rev. Mol. Cell Biol. 2007, 8, 185-194. [CrossRef]

31. Ferreira, A.P.A.; Boucrot, E. Mechanisms of Carrier Formation during Clathrin-Independent Endocytosis. Trends Cell Biol. 2018, 28, 188-200. [CrossRef] [PubMed]

32. Sezgin, E.; Levental, I.; Mayor, S.; Eggeling, C. The mystery of membrane organization: Composition, regulation and roles of lipid rafts. Nat. Rev. Mol. Cell Biol. 2017, 18, 361-374. [CrossRef] [PubMed]

33. Beck-García, K.; Beck-García, E.; Bohler, S.; Zorzin, C.; Sezgin, E.; Levental, I.; Alarcón, B.; Schamel, W.W. Nanoclusters of the resting T cell antigen receptor (TCR) localize to non-raft domains. Biochim. Biophys. Acta. 2015, 1853, 802-809. [CrossRef] [PubMed]

34. Sproul, T.W.; Malapati, S.; Kim, J.; Pierce, S.K. Cutting edge: B cell antigen receptor signaling occurs outside lipid rafts in immature B cells. J. Immunol. 2000, 165, 6020-6023. [CrossRef] [PubMed]

35. Razani, B.; Rubin, C.S.; Lisanti, M.P. Regulation of cAMP-mediated signal transduction via interaction of caveolins with the catalytic subunit of protein kinase A. J. Biol. Chem. 1999, 274, 26353-26360. [CrossRef] [PubMed]

36. Teissier, E.; Pécheur, E.I. Lipids as modulators of membrane fusion mediated by viral fusion proteins. Eur. Biophys. J. 2007, 36, 887-899. [CrossRef]

37. Ewers, H.; Helenius, A. Lipid-mediated endocytosis. Cold Spring Harb. Perspect. Biol. 2011, 3, a004721. [CrossRef]

38. Fecchi, K.; Anticoli, S.; Peruzzu, D.; Iessi, E.; Gagliardi, M.C.; Matarrese, P.; Ruggieri, A. Coronavirus Interplay with Lipid Rafts and Autophagy Unveils Promising Therapeutic Targets. Front. Microbiol. 2020, 11, 1821. [CrossRef]

39. Dick, R.A.; Goh, S.L.; Feigenson, G.W.; Vogt, V.M. HIV-1 Gag protein can sense the cholesterol and acyl chain environment in model membranes. Proc. Natl. Acad. Sci USA 2012, 109, 18761-18766. [CrossRef]

40. Nabi, I.R.; Le, P.U. Caveolae/raft-dependent endocytosis. J. Cell Biol. 2003, 161, 673-677. [CrossRef]

41. Droese, J.; Mokros, T.; Hermosilla, R.; Schülein, R.; Lipp, M.; Höpken, U.E.; Rehm, A. HCMV-encoded chemokine receptor US28 employs multiple routes for internalization. Biochem. Biophys. Res. Commun. 2004, 322, 42-49. [CrossRef] [PubMed]

42. Limaye, A.P.; Babu, T.M.; Boeckh, M. Progress and Challenges in the Prevention, Diagnosis, and Management of Cytomegalovirus Infection in Transplantation. Clin. Microbiol. Rev. 2020, 34. [CrossRef] [PubMed]

43. Kledal, T.N.; Rosenkilde, M.M.; Schwartz, T.W. Selective recognition of the membrane-bound CX3C chemokine, fractalkine, by the human cytomegalovirus-encoded broad-spectrum receptor US28. FEBS Lett. 1998, 441, 209-214. [CrossRef]

44. Neote, K.; DiGregorio, D.; Mak, J.Y.; Horuk, R.; Schall, T.J. Molecular cloning, functional expression, and signaling characteristics of a C-C chemokine receptor. Cell 1993, 72, 415-425. [CrossRef]

45. McLean, K.A.; Holst, P.J.; Martini, L.; Schwartz, T.W.; Rosenkilde, M.M. Similar activation of signal transduction pathways by the herpesvirus-encoded chemokine receptors US28 and ORF74. Virology 2004, 325, 241-251. [CrossRef]

46. Krishna, B.A.; Spiess, K.; Poole, E.L.; Lau, B.; Voigt, S.; Kledal, T.N.; Rosenkilde, M.M.; Sinclair, J.H. Targeting the latent cytomegalovirus reservoir with an antiviral fusion toxin protein. Nat. Commun. 2017, 8, 14321. [CrossRef]

47. Spiess, K.; Jeppesen, M.G.; Malmgaard-Clausen, M.; Krzywkowski, K.; Dulal, K.; Cheng, T.; Hjorto, G.M.; Larsen, O.; Burg, J.S.; Jarvis, M.A.; et al. Rationally designed chemokine-based toxin targeting the viral G protein-coupled receptor US28 potently inhibits cytomegalovirus infection in vivo. Proc. Natl. Acad. Sci. USA 2015, 112, 8427-8432. [CrossRef]

48. Spiess, K.; Jeppesen, M.G.; Malmgaard-Clausen, M.; Krzywkowski, K.; Kledal, T.N.; Rosenkilde, M.M. Novel Chemokine-Based Immunotoxins for Potent and Selective Targeting of Cytomegalovirus Infected Cells. J. Immunol. Res. 2017, 2017, 4069260. [CrossRef]

49. Fraile-Ramos, A.; Pelchen-Matthews, A.; Kledal, T.N.; Browne, H.; Schwartz, T.W.; Marsh, M. Localization of HCMV UL33 and US27 in endocytic compartments and viral membranes. Traffic 2002, 3, 218-232. [CrossRef] 
50. Wagner, S.; Arnold, F.; Wu, Z.; Schubert, A.; Walliser, C.; Tadagaki, K.; Jockers, R.; Mertens, T.; Michel, D. The 7-transmembrane protein homologue UL78 of the human cytomegalovirus forms oligomers and traffics between the plasma membrane and different intracellular compartments. Arch. Virol. 2012, 157, 935-949. [CrossRef]

51. Ahuja, S.K.; Murphy, P.M. Molecular piracy of mammalian interleukin-8 receptor type B by herpesvirus saimiri. J. Biol. Chem. 1993, 268, 20691-20694. [PubMed]

52. Rosenkilde, M.M.; Kledal, T.N.; Brauner-Osborne, H.; Schwartz, T.W. Agonists and inverse agonists for the herpesvirus 8-encoded constitutively active seven-transmembrane oncogene product, ORF-74. J. Biol. Chem. 1999, 274, 956-961. [CrossRef] [PubMed]

53. Rosenkilde, M.M.; Kledal, T.N.; Holst, P.J.; Schwartz, T.W. Selective elimination of high constitutive activity or chemokine binding in the human herpesvirus 8 encoded seven transmembrane oncogene ORF74. J. Biol. Chem. 2000, 275, 26309-26315. [CrossRef] [PubMed]

54. Rosenkilde, M.M.; Schwartz, T.W. Potency of ligands correlates with affinity measured against agonist and inverse agonists but not against neutral ligand in constitutively active chemokine receptor. Mol. Pharm. 2000, 57, 602-609. [CrossRef] [PubMed]

55. Rosenkilde, M.M.; McLean, K.A.; Holst, P.J.; Schwartz, T.W. The CXC chemokine receptor encoded by herpesvirus saimiri, ECRF3, shows ligand-regulated signaling through Gi, Gq, and G12/13 proteins but constitutive signaling only through Gi and G12/13 proteins. J. Biol. Chem. 2004, 279, 32524-32533. [CrossRef] [PubMed]

56. Yang, T.Y.; Chen, S.C.; Leach, M.W.; Manfra, D.; Homey, B.; Wiekowski, M.; Sullivan, L.; Jenh, C.H.; Narula, S.K.; Chensue, S.W.; et al. Transgenic expression of the chemokine receptor encoded by human herpesvirus 8 induces an angioproliferative disease resembling Kaposi's sarcoma. J. Exp. Med. 2000, 191, 445-454. [CrossRef]

57. Holst, P.J.; Rosenkilde, M.M.; Manfra, D.; Chen, S.C.; Wiekowski, M.T.; Holst, B.; Cifire, F.; Lipp, M.; Schwartz, T.W.; Lira, S.A. Tumorigenesis induced by the HHV8-encoded chemokine receptor requires ligand modulation of high constitutive activity. J. Clin. Investig. 2001, 108, 1789-1796. [CrossRef]

58. Grisotto, M.G.; Garin, A.; Martin, A.P.; Jensen, K.K.; Chan, P.; Sealfon, S.C.; Lira, S.A. The Human Herpesvirus 8 Chemokine Receptor vGPCR Triggers Autonomous Proliferation of Endothelial Cells. J. Clin. Investig. 2006, 116. [CrossRef]

59. De Munnik, S.M.; Smit, M.J.; Leurs, R.; Vischer, H.F. Modulation of cellular signaling by herpesvirus-encoded G protein-coupled receptors. Front. Pharm. 2015, 6. [CrossRef]

60. Paulsen, S.J.; Rosenkilde, M.M.; Eugen-Olsen, J.; Kledal, T.N. Epstein-Barr virus-encoded BILF1 is a constitutively active $\mathrm{G}$ protein-coupled receptor. J. Virol. 2005, 79, 536-546. [CrossRef]

61. Chmielewicz, B.; Goltz, M.; Franz, T.; Bauer, C.; Brema, S.; Ellerbrok, H.; Beckmann, S.; Rziha, H.-J.; Lahrmann, K.-H.; Romero, C.; et al. A novel porcine gammaherpesvirus. Virology 2003, 308, 317-329. [CrossRef]

62. Lindner, I.; Ehlers, B.; Noack, S.; Dural, G.; Yasmum, N.; Bauer, C.; Goltz, M. The porcine lymphotropic herpesvirus 1 encodes functional regulators of gene expression. Virology 2007, 357, 134-148. [CrossRef] [PubMed]

63. Spiess, K.; Fares, S.; Sparre-Ulrich, A.H.; Hilgenberg, E.; Jarvis, M.A.; Ehlers, B.; Rosenkilde, M.M. Identification and functional comparison of seven-transmembrane G-protein-coupled BILF1 receptors in recently discovered nonhuman primate lymphocryptoviruses. J. Virol. 2015, 89, 2253-2267. [CrossRef] [PubMed]

64. Goltz, M.; Ericsson, T.; Patience, C.; Huang, C.A.; Noack, S.; Sachs, D.H.; Ehlers, B. Sequence analysis of the genome of porcine lymphotropic herpesvirus 1 and gene expression during posttransplant lymphoproliferative disease of pigs. Virology 2002, 294, 383-393. [CrossRef]

65. Hart, J.; Ackermann, M.; Jayawardane, G.; Russell, G.; Haig, D.M.; Reid, H.; Stewart, J.P. Complete sequence and analysis of the ovine herpesvirus 2 genome. J. Gen. Virol. 2007, 88, 28-39. [CrossRef]

66. Boudry, C.; Markine-Goriaynoff, N.; Delforge, C.; Springael, J.Y.; de Leval, L.; Drion, P.; Russell, G.; Haig, D.M.; Vanderplasschen, A.F.; Dewals, B. The A5 gene of alcelaphine herpesvirus 1 encodes a constitutively active G-protein-coupled receptor that is non-essential for the induction of malignant catarrhal fever in rabbits. J. Gen. Virol. 2007, 88, 3224-3233. [CrossRef] 
67. Griffin, B.D.; Gram, A.M.; Mulder, A.; Van Leeuwen, D.; Claas, F.H.; Wang, F.; Ressing, M.E.; Wiertz, E. EBV BILF1 evolved to downregulate cell surface display of a wide range of HLA class I molecules through their cytoplasmic tail. J. Immunol. 2013, 190, 1672-1684. [CrossRef]

68. Zhang, X.; Kim, K.M. Multifactorial Regulation of G Protein-Coupled Receptor Endocytosis. Biomol. Ther. 2017, 25, 26-43. [CrossRef]

69. Foster, S.R.; Bräuner-Osborne, H. Investigating Internalization and Intracellular Trafficking of GPCRs: New Techniques and Real-Time Experimental Approaches. Handb. Exp. Pharm. 2018, 245, 41-61. [CrossRef]

70. Arancibia-Cárcamo, I.L.; Fairfax, B.P.; Moss, S.J.; Kittler, J.T. Studying the Localization, Surface Stability and Endocytosis of Neurotransmitter Receptors by Antibody Labeling and Biotinylation Approaches. Available online: https://www.ncbi.nlm.nih.gov/books/NBK2552/ (accessed on 26 November 2020).

71. Fraile-Ramos, A.; Kledal, T.N.; Pelchen-Matthews, A.; Bowers, K.; Schwartz, T.W.; Marsh, M. The human cytomegalovirus US28 protein is located in endocytic vesicles and undergoes constitutive endocytosis and recycling. Mol. Biol. Cell 2001, 12, 1737-1749. [CrossRef]

72. Hislop, J.N.; von Zastrow, M. Analysis of GPCR localization and trafficking. Methods Mol. Biol. 2011, 746, 425-440. [CrossRef] [PubMed]

73. Cossarizza, A.; Chang, H.D.; Radbruch, A.; Acs, A.; Adam, D.; Adam-Klages, S.; Agace, W.W.; Aghaeepour, N.; Akdis, M.; Allez, M.; et al. Guidelines for the use of flow cytometry and cell sorting in immunological studies (second edition). Eur. J. Immunol. 2019, 49, 1457-1973. [CrossRef] [PubMed]

74. Delgado-Peraza, F.; Nogueras-Ortiz, C.; Acevedo Canabal, A.M.; Roman-Vendrell, C.; Yudowski, G.A. Imaging GPCRs trafficking and signaling with total internal reflection fluorescence microscopy in cultured neurons. Methods Cell Biol. 2016, 132, 25-33. [CrossRef]

75. Shashkova, S.; Leake, M. Single-molecule fluorescence microscopy review: Shedding new light on old problems. Biosci. Rep. 2017, 37. [CrossRef] [PubMed]

76. Reck-Peterson, S.L.; Derr, N.D.; Stuurman, N. Imaging single molecules using total internal reflection fluorescence microscopy (TIRFM). Cold Spring Harb. Protoc. 2010, 2010, pdb.top73. [CrossRef] [PubMed]

77. Wandinger-Ness, A.; Zerial, M. Rab proteins and the compartmentalization of the endosomal system. Cold Spring Harb. Perspect. Biol. 2014, 6, a022616. [CrossRef]

78. Dutta, D.; Donaldson, J.G. Search for inhibitors of endocytosis: Intended specificity and unintended consequences. Cell Logist. 2012, 2, 203-208. [CrossRef]

79. Wang, L.H.; Rothberg, K.G.; Anderson, R.G. Mis-assembly of clathrin lattices on endosomes reveals a regulatory switch for coated pit formation. J. Cell Biol. 1993, 123, 1107-1117. [CrossRef]

80. Macia, E.; Ehrlich, M.; Massol, R.; Boucrot, E.; Brunner, C.; Kirchhausen, T. Dynasore, a cell-permeable inhibitor of dynamin. Dev. Cell 2006, 10, 839-850. [CrossRef]

81. Hall, B.; Limaye, A.; Kulkarni, A.B. Overview: Generation of gene knockout mice. Curr. Protoc. Cell Biol. 2009, 44. [CrossRef]

82. Kohout, T.A.; Lin, F.T.; Perry, S.J.; Conner, D.A.; Lefkowitz, R.J. $\beta$-Arrestin 1 and 2 differentially regulate heptahelical receptor signaling and trafficking. Proc. Natl. Acad. Sci. USA 2001, 98, 1601-1606. [CrossRef]

83. Williams, B.O.; Warman, M.L. CRISPR/CAS9 Technologies. J. Bone Min. Res. 2017, 32, 883-888. [CrossRef] [PubMed]

84. Reis, C.R.; Chen, P.H.; Srinivasan, S.; Aguet, F.; Mettlen, M.; Schmid, S.L. Crosstalk between Akt/GSK3 $\beta$ signaling and dynamin-1 regulates clathrin-mediated endocytosis. EMBO J. 2015, 34, 2132-2146. [CrossRef] [PubMed]

85. Van der Bliek, A.M.; Redelmeier, T.E.; Damke, H.; Tisdale, E.J.; Meyerowitz, E.M.; Schmid, S.L. Mutations in human dynamin block an intermediate stage in coated vesicle formation. J. Cell Biol. 1993, 122, 553-563. [CrossRef] [PubMed]

86. Krupnick, J.G.; Santini, F.; Gagnon, A.W.; Keen, J.H.; Benovic, J.L. Modulation of the arrestin-clathrin interaction in cells. Characterization of beta-arrestin dominant-negative mutants. J. Biol. Chem. 1997, 272, 32507-32512. [CrossRef]

87. Shigematsu, S.; Watson, R.T.; Khan, A.H.; Pessin, J.E. The adipocyte plasma membrane caveolin functional/structural organization is necessary for the efficient endocytosis of GLUT4. J. Biol. Chem. 2003, 278, 10683-10690. [CrossRef]

88. Benmerah, A.; Bayrou, M.; Cerf-Bensussan, N.; Dautry-Varsat, A. Inhibition of clathrin-coated pit assembly by an Eps15 mutant. J. Cell Sci. 1999, 112, 1303-1311. 
89. Chen, C.; Zhuang, X. Epsin 1 is a cargo-specific adaptor for the clathrin-mediated endocytosis of the influenza virus. Proc. Natl. Acad. Sci. USA 2008, 105, 11790-11795. [CrossRef]

90. Kubale, V.; Abramović, Z.; Pogacnik, A.; Heding, A.; Sentjurc, M.; Vrecl, M. Evidence for a role of caveolin-1 in neurokinin-1 receptor plasma-membrane localization, efficient signaling, and interaction with beta-arrestin 2. Cell Tissue Res. 2007, 330, 231-245. [CrossRef]

91. Cunningham, C.M.; Bellipanni, G.; Habas, R.; Balciunas, D. Deletion of morpholino binding sites (DeMOBS) to assess specificity of morphant phenotypes. Sci. Rep. 2020, 10, 15366. [CrossRef]

92. Eisen, J.S.; Smith, J.C. Controlling morpholino experiments: Don't stop making antisense. Development 2008, 135, 1735-1743. [CrossRef]

93. Leung, T.; Humbert, J.E.; Stauffer, A.M.; Giger, K.E.; Chen, H.; Tsai, H.J.; Wang, C.; Mirshahi, T.; Robishaw, J.D. The orphan G protein-coupled receptor 161 is required for left-right patterning. Dev. Biol. 2008, 323, 31-40. [CrossRef] [PubMed]

94. Bryja, V.; Gradl, D.; Schambony, A.; Arenas, E.; Schulte, G. Beta-arrestin is a necessary component of Wnt/beta-catenin signaling in vitro and in vivo. Proc. Natl. Acad. Sci. USA 2007, 104, 6690-6695. [CrossRef] [PubMed]

95. Moore, P.S.; Boshoff, C.; Weiss, R.A.; Chang, Y. Molecular mimicry of human cytokine and cytokine response pathway genes by KSHV. Science 1996, 274, 1739-1744. [CrossRef]

96. Maussang, D.; Verzijl, D.; van Walsum, M.; Leurs, R.; Holl, J.; Pleskoff, O.; Michel, D.; van Dongen, G.A.; Smit, M.J. Human cytomegalovirus-encoded chemokine receptor US28 promotes tumorigenesis. Proc. Natl. Acad. Sci. USA 2006, 103, 13068-13073. [CrossRef] [PubMed]

97. Miller, W.E.; Zagorski, W.A.; Brenneman, J.D.; Avery, D.; Miller, J.L.; O'Connor, C.M. US28 is a potent activator of phospholipase C during HCMV infection of clinically relevant target cells. PLoS ONE 2012, 7, e50524. [CrossRef] [PubMed]

98. Lyngaa, R.; Norregaard, K.; Kristensen, M.; Kubale, V.; Rosenkilde, M.M.; Kledal, T.N. Cell transformation mediated by the Epstein-Barr virus $\mathrm{G}$ protein-coupled receptor BILF1 is dependent on constitutive signaling. Oncogene 2010, 29, 4388-4398. [CrossRef]

99. Miller, W.E.; Houtz, D.A.; Nelson, C.D.; Kolattukudy, P.E.; Lefkowitz, R.J. G-protein-coupled receptor (GPCR) kinase phosphorylation and beta-arrestin recruitment regulate the constitutive signaling activity of the human cytomegalovirus US28 GPCR. J. Biol. Chem. 2003, 278, 21663-21671. [CrossRef]

Publisher's Note: MDPI stays neutral with regard to jurisdictional claims in published maps and institutional affiliations.

(C) 2020 by the authors. Licensee MDPI, Basel, Switzerland. This article is an open access article distributed under the terms and conditions of the Creative Commons Attribution (CC BY) license (http://creativecommons.org/licenses/by/4.0/). 